HELMINTHOLOGIA, 57, 2: 145 - 153, 2020

\title{
Short-term effects of cadmium and mercury on soil nematode communities in a pot experiment
}

\author{
Y. LÜ1, X. CHEN², W. F. XUE'², W. D. ZHANG $3, *$ \\ ${ }^{1}$ China Certification \& Inspection Group LiaoNing Co.Ltd., ${ }^{2}$ Technology Center, Dalian Customs District, People's Republic of China;

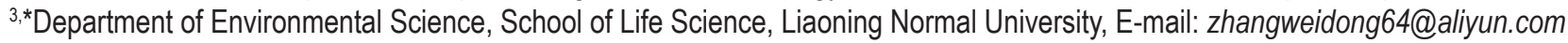

Article info

Received September 14, 2019

Accepted December 26, 2019

\section{Summary}

Analysis of soil nematode feeding groups and functional guilds were used as a valuable tool to detect heavy metal pollution. Effects of cadmium $(\mathrm{Cd})$ at $5 \mathrm{mg} / \mathrm{kg}$, mercury $(\mathrm{Hg})$ at $20 \mathrm{mg} / \mathrm{kg}$, combined $\mathrm{Cd}$ and $\mathrm{Hg}$ at $5+20 \mathrm{mg} / \mathrm{kg}$ on the nematode communities were studied after three months application. Nematodes were collected from soil in rhizosphere of Morning glories (Pharhiris nil) which were applied as heavy metal accumulators and were grown in the experimental pots. Both single and combined heavy metals had marked effects on the nematode abundance, life-history strategies and feeding type composition. Bacteriovores and c-p 2 group were found to be the most abundant trophic group and functional guild, respectively. Acrobeloides and Pratylenchus were the most two abundant genera, decreasing number of them was responsible for the significant difference between control and polluted treatments. $\mathrm{Cd}-5$ and $\mathrm{Cd}-\mathrm{Hg} 5+20$ presented lower values of nematode diversity index $\left(\mathrm{H}^{\prime}\right)$ and evenness index ( $\left.\mathrm{J}^{\prime}\right)$ than $\mathrm{Hg}-20$. The combination of $\mathrm{Cd}$ and $\mathrm{Hg}$ showed lower nematode trophic diversity (TD), in comparison with single $\mathrm{Cd}$ or $\mathrm{Hg}$. Conversely, heavy metals addition exhibited no pronounced effect on Maturity index (MI), structural index (SI) and enrichment index (EI). Our results demonstrate that genera composition is a better indicator to short-term heavy metal effects than some common indicator indices and emphasize that deeper assemblage analyses are needed for a correct interpretation of short-term disturbance on soil nematodes.

Keywords: Morning glory; heavy metals; nematodes; trophic group; c-p group

\section{Introduction}

Anthropic activities such as mining, manufacturing, transporting and fertilizing have caused heavy metal contamination in urban and agricultural soils. The heavy metal contamination has resulted in severe threats to human and environment health (Chen et al., 2005; Xia et al., 2004). Cadmium (Cd) and mercury (Hg) are the two most predominant metals in sewage irrigation region of Liaoning province (Li \& Tong 2008). How to deal with the toxic pollutants efficiently and safely is becoming one of the most popu- lar environmental-related themes. Phytoremediation has been developed in recent years (Yoon 2007), and has become a new economical method which can reduce some toxic pollutants in an environmentally friendly way (Pilon-Smits, 2005). Morning glory (Pharhiris nil) is a remediation plant which absorbs pollutants from soil and accumulates them in stalk, leaf, and root, in this way, contaminant could be reduced through harvesting the plant body. Xu et al. (2012) reported that petroleum degrading rate was increased by $13 \%$ after 2 months of planting Morning glory. With respect to metal bioaccumulation, plants accumulated higher amounts of

\footnotetext{
$\bar{*}$ - corresponding author
} 
metal in root than stem in previous studies (Ali et al., 2004), so the toxicity created by heavy metals impacts roots first, which means soil quality and plant-microbe interactions around the rhizosphere can influence the efficiency of metal phytoremediation (Cherian \& Oliveira 2005). However, most investigations about accumulating plants were focused on the aboveground parts, the structure and assemblage of soil fauna around rhizosphere are not well known. Nematodes are one of the most abundant groups of soil invertebrates (Fu et al., 2000) and occupy a central position in the soil food web. Soil nematode communities can provide unique insights into soil processes and supply useful information about soil environment. Soil nematode as an indicator for heavy metal pollution has been widely studied in recent years. (Zhang et al., 2011; Šalamún, 2011; Martinez et al., 2018). Most of previous studies took place in an open environment such as mining area, however, under laboratory condition, the characteristics of rhizosphere nematode communities affected by specific concentrations of single and mixed heavy metals are not well studied. The present study investigated the changes of $\mathrm{Cd}, \mathrm{Hg}$ and $\mathrm{Cd}+\mathrm{Hg}$ concentrations after 90 days remediation and characterized the nematode community structure and assemblage around rhizosphere of Morning glory. The objectives of this study were: 1) to evaluate soil quality after phytoremediation experiment; 2) to represent the responses of nematodes to different heavy metal treatments; 3 ) to provide basic data for using soil nematodes to assess the level of phytoremediation. We hypothesize that only small part of heavy metals could be absorbed by plants during short-term remediation, hence the remaining part still has adverse effects on nematode communities, furthermore, the degree of influence may depend on feeding groups and life-history strategies.

\section{Material and Methods}

The seeds of Morning glory were planted in non-contaminated garden soil for 7 days before experiment, then, five seedlings were subsequently transplanted into one pot. Each pot $(15 \mathrm{~cm}-$ diam $\times 12 \mathrm{~cm}-$-depth) was loaded by $600 \mathrm{~g}$ soil collected from Da- lian Xishan National Forest Park, soil was loamy with $13.1 \%$ clay, $50.4 \%$ silt and $36.5 \%$ sand and was completely mixed. Based on the concentrations of heavy metals obtained from the wastewater irrigation area (max concentration of $\mathrm{Cd}=5 \mathrm{mg} / \mathrm{kg}$ ) (Liao, 1993) and mercury mining area $(\mathrm{Hg}=20.4 \mathrm{mg} / \mathrm{kg}$ ) (Yu et al., 2017), the concentrations of heavy metal were selected at Cd-5mg/kg, Hg$20 \mathrm{mg} / \mathrm{kg}$ and $\mathrm{Cd}-\mathrm{Hg} 5+20 \mathrm{mg} / \mathrm{kg}$. Heave metal solutions were applied as $\mathrm{Cd}\left(\mathrm{NO}_{3}\right)_{2} \cdot 4 \mathrm{H}_{2} \mathrm{O}$ and $\mathrm{HgCl}_{2}$, three replicates at each level were established, concentrations of heavy metals before and after treatment were shown in Table 1. The seedlings were grown for three months in a climate chamber at $20 \pm 1^{\circ} \mathrm{C}$. Intensity of light was $5000 \mathrm{LX}$ with 16 hour of light alternating with 8 hour of darkness. Each pot was watered with $250 \mathrm{ml}$ deionized water every 2 days.

Nematodes were extracted from $100 \mathrm{~g}$ (fresh weight) soil per pot using elutriate-sieving-flotation and centrifugation method (Barker et al., 1985). Extracted nematodes were heat killed at $60^{\circ} \mathrm{C}$, counted and preserved in $4 \%$ formalin aqueous solution (Steinberger \& Sarig, 1993). One hundred nematodes randomly selected specimens per sample were identified to genus level using Olympus inverted compound microscope based on stoma and esophageal morphology (Liang et al., 2001, 2003). The genus was identified according to Bongers (1988) and Li et al. (2017).

Soil moisture of each sample was gravimetric determined by weight loss at $105{ }^{\circ} \mathrm{C}$ for 8 hours and expressed as percent dry weight. Another $100 \mathrm{~g}$ fresh soil per pot was air-dried for 14 days at room temperature to text soil organic matter and heavy metals. Electronic $\mathrm{pH}$ meter (model SevenGo ${ }^{\mathrm{TM}} \mathrm{pH}-\mathrm{SG} 2$ ), the potassium dichromate external heating method, graphite furnace atomic absorption spectrometry and microwave dissolution/atomic fluorescence spectrometry were used to determined soil $\mathrm{pH}$, organic matter, $\mathrm{Cd}$ and $\mathrm{Hg}$, respectively (Ru, 1999; China National Environmental Monitoring Centre,1997; Ministry of Ecology and Environment of the People's Republic of China,2013).

The assemblage and characteristics of nematode community were investigated by following approaches: (1) feeding groups (bacterivores-BF, fungivores-FF, plant parasites-PP, omnivores-predators-

Table 1. Soil chemical properties and heavy metal concentrations.

\begin{tabular}{|c|c|c|c|c|c|c|}
\hline \multicolumn{2}{|c|}{$\begin{array}{l}\text { Heavy metals } \\
\text { addition } \\
(\mathrm{mg} / \mathrm{kg})\end{array}$} & \multicolumn{2}{|c|}{$\begin{array}{l}\text { Heavy metals contents after } \\
\text { remediation } \\
(\mathrm{mg} / \mathrm{kg})\end{array}$} & \multirow[t]{2}{*}{$\begin{array}{l}\text { Average root } \\
\text { weight (g/ } \\
\text { DW plant) }\end{array}$} & \multirow[t]{2}{*}{$\mathrm{pH}$} & \multirow[t]{2}{*}{$\begin{array}{l}\text { Soil organic } \\
\text { matter } \\
(\mathrm{g} / \mathrm{kg})\end{array}$} \\
\hline $\mathrm{Cd}$ & $\mathrm{Hg}$ & $\mathrm{Cd}$ & $\mathrm{Hg}$ & & & \\
\hline 0 & 0 & $0.21 \pm 0.01$ & $0.14 \pm 0.01$ & 0.023 & $6.86 \pm 0.27 a$ & $40.76 \pm 1.95 a$ \\
\hline 5 & 0 & $4.12 \pm 0.32$ & $0.13 \pm 0.01$ & 0.032 & $6.33 \pm 0.21 b$ & $42.88 \pm 1.54 a$ \\
\hline 0 & 20 & $0.21 \pm 0.01$ & $18.17 \pm 0.67$ & 0.024 & $6.68 \pm 0.30 \mathrm{ab}$ & $41.31 \pm 2.86 a$ \\
\hline 5 & 20 & $4.19 \pm 0.45$ & $16.38 \pm 0.58$ & 0.036 & $6.42 \pm 0.33 a b$ & $40.69 \pm 3.07 a$ \\
\hline
\end{tabular}

Heavy metal, root weight and pH data were supplied by Hou (2012); Mean values in a line with different letters are significantly different from each other at $P<0.05$; values are expressed as mean \pm standard error $(n=3)$. 
OP) (Yeates et al., 1993; Pen-Mouratov et al., 2004); (2) life-history groups ( $c-p$ values range from 1 to 5 represent colonizers to persistors (Bongers, 1990, 1999). (3) ratio of $\mathrm{f} / \mathrm{b}$ (fungivores/ bacterivores); (4) diversity index $H^{\prime}=-\sum$ ni (Inni) where ni is the proportion of individuals in the i-th taxon (Shannon \& Weaver, 1949) , (5) trophic diversity index TD $=T D=1 / \sum$ pi2, where pi is the proportion of each trophic group; (6) evenness $J^{\prime}=H^{\prime} / \mathrm{ln}(\mathrm{S})$, where $S$ is the number of taxa; (7) maturity indices $\mathrm{Ml}=\sum$ vifi, where vi is the $c-p$ value of the $i-$ th taxa and fi is the frequency of the $i-$ th taxa in the sample (excluding PP) (Bongers, 1990); (8) enrichment index (EI) and structure index (SI), EI = 100(e/e + b), SI = 100(s/s + b), where $e=\sum$ kene, $s=\sum k s n s$, and $b=\sum k b n b$ (Ferris et al., 2001). All nematode data were $1 n(x+1)$ transformed prior to statistical analysis. The significance of the effects of heavy metals on nematode communities was tested by one-way analysis of variance (ANOVA), SPSS 18.0 statistical software, and means compared by LSD's Test (Least Significant Difference). Differences with $P$ $<0.05$ were considered significant. Principal component analysis

Table 2. Relative abundance (\%) of nematode genera in control (CK) and polluted pots.

\begin{tabular}{|c|c|c|c|c|c|}
\hline Genus & Guild & CK & Cd-5 & $\mathrm{Hg}-20$ & $\mathrm{Cd} 5+\mathrm{Hg} 20$ \\
\hline Panagrolaimus & BF1 & $0.62 \pm 0.61 b$ & $0.00 \pm 0.00 \mathrm{~b}$ & $5.51 \pm 1.14 a$ & $5.15 \pm 0.67 a$ \\
\hline Rhabditis & BF1 & $11.04 \pm 0.86 a$ & $3.33 \pm 3.33 b$ & $9.74 \pm 1.12 a b$ & $7.72 \pm 1.92 a b$ \\
\hline Mesorhabditis & BF1 & $3.46 \pm 1.03 a$ & $1.75 \pm 1.75 a$ & $4.23 \pm 0.38 a$ & $2.29 \pm 1.17 a$ \\
\hline Acrobeles & BF2 & $1.68 \pm 0.92 a$ & $0.00 \pm 0.00 a$ & $1.28 \pm 1.28 a$ & $0.00 \pm 0.00 \mathrm{a}$ \\
\hline Acrobeloides & $\mathrm{BF} 2$ & $32.30 \pm 1.52 a b$ & $29.70 \pm 2.68 \mathrm{ab}$ & $27.95 \pm 4.56 b$ & $42.18 \pm 6.71 a$ \\
\hline Heterocephalobus & BF2 & $2.89 \pm 0.56 a$ & $1.75 \pm 1.75 a$ & $1.67 \pm 1.67 a$ & $1.01 \pm 1.01 \mathrm{a}$ \\
\hline Eucephalobus & BF2 & $2.27 \pm 0.46 a$ & $0.00 \pm 0.00 a$ & $2.56 \pm 1.23 a$ & $3.57 \pm 2.23 a$ \\
\hline Cervidellus & BF2 & $0.61 \pm 0.61 a$ & $0.00 \pm 0.00 a$ & $1.28 \pm 1.28 a$ & $1.01 \pm 1.01 \mathrm{a}$ \\
\hline Plectus & BF2 & $0.60 \pm 0.60 \mathrm{a}$ & $0.00 \pm 0.00 a$ & $1.28 \pm 1.28 a$ & $1.28 \pm 1.28 \mathrm{a}$ \\
\hline Chrohogaster & BF2 & $0.53 \pm 0.53 a$ & $0.00 \pm 0.00 \mathrm{a}$ & $0.00 \pm 0.00 \mathrm{a}$ & $1.01 \pm 1.01 \mathrm{a}$ \\
\hline Prismatolaimus & BF3 & $1.19 \pm 1.03 a$ & $5.46 \pm 3.21 a$ & $0.00 \pm 0.00 a$ & $2.29 \pm 1.17 a$ \\
\hline Alaimus & BF4 & $2.20 \pm 1.39 b$ & $0.00 \pm 0.00 b$ & $0.00 \pm 0.00 \mathrm{~b}$ & $5.43 \pm 1.35 a$ \\
\hline Paraphelenchus & FF2 & $0.53 \pm 0.53 b$ & $0.00 \pm 0.00 b$ & $0.00 \pm 0.00 b$ & $5.43 \pm 1.35 a$ \\
\hline Pseudhalenchus & FF2 & $0.61 \pm 0.61 a$ & $0.00 \pm 0.00 \mathrm{a}$ & $0.00 \pm 0.00 \mathrm{a}$ & $0.00 \pm 0.00 \mathrm{a}$ \\
\hline Aphelenchoides & FF2 & $8.19 \pm 1.78 a$ & $6.94 \pm 1.53 a b$ & $2.95 \pm 1.51 b$ & $1.01 \pm 1.01 b$ \\
\hline Bursaphelenchus & FF2 & $0.00 \pm 0.00 \mathrm{a}$ & $0.00 \pm 0.00 a$ & $2.56 \pm 1.28 \mathrm{a}$ & $1.28 \pm 1.28 \mathrm{a}$ \\
\hline Filenchus & FF2 & $5.79 \pm 0.71 b$ & $5.27 \pm 0.16 b$ & $27.56 \pm 1.70 a$ & $1.01 \pm 1.01 \mathrm{c}$ \\
\hline Diphtherophora & FF3 & $0.53 \pm 0.53 a b$ & $3.42 \pm 1.71 \mathrm{a}$ & $0.00 \pm 0.00 \mathrm{~b}$ & $1.01 \pm 1.01 \mathrm{ab}$ \\
\hline Paratylenchus & PP2 & $17.62 \pm 0.52 b$ & $33.58 \pm 4.33 a$ & $8.19 \pm 2.05 c$ & $10.14 \pm 3.30 \mathrm{bc}$ \\
\hline Helicotylenchus & PP3 & $0.00 \pm 0.00 \mathrm{~b}$ & $3.61 \pm 1.81 \mathrm{a}$ & $0.00 \pm 0.00 b$ & $1.01 \pm 1.01 \mathrm{ab}$ \\
\hline Heterodera & PP3 & $0.53 \pm 0.53 a$ & $1.67 \pm 1.67 a$ & $1.28 \pm 1.28 a$ & $1.01 \pm 1.01 \mathrm{a}$ \\
\hline Eudorylaimus & OP4 & $1.20 \pm 0.60 a$ & $3.52 \pm 1.77 a$ & $1.28 \pm 1.28 a$ & $2.29 \pm 1.17 a$ \\
\hline Aporcelaimellus & OP5 & $0.61 \pm 0.61 a$ & $0.00 \pm 0.00 \mathrm{a}$ & $0.00 \pm 0.00 a$ & $0.00 \pm 0.00 a$ \\
\hline Aporcelaimium & OP5 & $1.65 \pm 0.92 \mathrm{ab}$ & $0.00 \pm 0.00 \mathrm{a}$ & $2.95 \pm 1.51 b$ & $2.86 \pm 1.61 \mathrm{a}$ \\
\hline Prodorylaimus & OP5 & $0.61 \pm 0.61 a$ & $0.00 \pm 0.00 a$ & $0.00 \pm 0.00 a$ & $0.00 \pm 0.00 a$ \\
\hline Discolaimus & OP5 & $1.14 \pm 0.57 a$ & $0.00 \pm 0.00 \mathrm{~b}$ & $0.00 \pm 0.00 b$ & $0.00 \pm 0.00 b$ \\
\hline
\end{tabular}

$\mathrm{BF}$ : bacterivores, FF: fungivores, PP: plant parasites, OP: omnivores-predators, numbers following the letters in Guild indicate the c-p value of each taxon Mean values in a line with different letters are significantly different from each other at $P<0.05$; values are expressed as mean $\pm \operatorname{standard}$ error $(n=3)$. 
Table 3. Ecological indices for nematode community structure in different treatments.

\begin{tabular}{lcccc}
\hline & $\mathrm{CK}$ & $\mathrm{Cd} 5$ & $\mathrm{Hg} 20$ & $\mathrm{Cd}+\mathrm{Hg} 5+20$ \\
\hline $\mathrm{H}^{\prime}$ & $2.31 \pm 0.21 \mathrm{a}$ & $1.44 \pm 0.14 \mathrm{~b}$ & $1.91 \pm 0.20 \mathrm{ab}$ & $1.68 \pm 0.50 \mathrm{~b}$ \\
$\mathrm{TD}$ & $2.34 \pm 0.22 \mathrm{~b}$ & $2.85 \pm 0.20 \mathrm{a}$ & $2.42 \pm 0.06 \mathrm{~b}$ & $1.78 \pm 0.22 \mathrm{c}$ \\
$\mathrm{J}$ & $0.85 \pm 0.02 \mathrm{a}$ & $0.70 \pm 0.05 \mathrm{~b}$ & $0.84 \pm 0.03 \mathrm{a}$ & $0.70 \pm 0.07 \mathrm{~b}$ \\
$\mathrm{f} / \mathrm{b}$ & $0.25 \pm 0.07 \mathrm{~b}$ & $0.29 \pm 0.04 \mathrm{~b}$ & $0.55 \pm 0.02 \mathrm{a}$ & $0.10 \pm 0.02 \mathrm{c}$ \\
$\mathrm{MI}$ & $1.71 \pm 0.15 \mathrm{a}$ & $2.13 \pm 0.23 \mathrm{a}$ & $1.91 \pm 0.04 \mathrm{a}$ & $2.16 \pm 0.11 \mathrm{a}$ \\
$\mathrm{SI}$ & $47.61 \pm 7.76 \mathrm{a}$ & $35.12 \pm 17.40 \mathrm{a}$ & $25.76 \pm 6.71 \mathrm{a}$ & $43.58 \pm 0.13 \mathrm{a}$ \\
$\mathrm{El}$ & $64.19 \pm 4.25 \mathrm{a}$ & $39.15 \pm 15.42 \mathrm{a}$ & $61.98 \pm 1.05 \mathrm{a}$ & $49.04 \pm 15.73 \mathrm{a}$ \\
\hline
\end{tabular}

Mean values in a line with different letters are significantly different from each other at $P<0.05$; values are expressed as mean \pm standard error $(n=3)$.

(PCA) was applied to represent the composition of the soil nematode community using CANOCO software.

\section{Results}

Soil chemical properties and heavy metal concentrations

Soil $\mathrm{pH}$ dropped dramatically at $\mathrm{Cd}-5$, while soil organic matter increased slightly at $\mathrm{Cd}-5$ and $\mathrm{Hg}-20$. The absorption rates of heavy metals were $17.6 \%, 9.15 \%$ and $16.2 \%+18.1 \%$ for $\mathrm{Cd}-5, \mathrm{Hg}-20$ and $\mathrm{Cd}+\mathrm{Hg} 5+20$, respectively (Table1).

\section{Nematode abundance and ecological indices}

The average nematode abundance ranged from 150 to 812 individuals per $100 \mathrm{~g}$ dry soil. Significant difference in the total nematode abundance was found between the control and other treatments $(P<0.05)$ (Table 4). Twenty six nematode genera were identified; of them, 12 genera belonged to the bacteriovores, 4 to fungivores, 4 to plant parasites and 6 to omnivores and predators. Acrobeloides was the most abundant genus in all treatments with the highest dominance (42.18\%) at $\mathrm{Cd}-\mathrm{Hg} 5+20$; Pratylenchus dominated the control, $\mathrm{Cd}-5$ and $\mathrm{Cd}-\mathrm{Hg} 5+20$; Rhabditis dominated the control (Table 2). All samples with heavy metal contamination appeared to be dissimilar from the control. The distinction between $\mathrm{Cd}-5$ and $\mathrm{CK}$ was most pronounced, whereas the distinction between $\mathrm{Hg}-20$ and $\mathrm{Cd}-\mathrm{Hg} 5+20$ was not obvious. The abundance of Panagrolaimus and Bursaphelenchus were positively correlated with $\mathrm{Hg}$ and $\mathrm{Cd}-\mathrm{Hg}$. The abundance of Helicotylenchus was strongly related to Cd (Fig. 1).

Both single and joint toxicity of $\mathrm{Cd}$ and $\mathrm{Hg}$ to the nematode ecological indices were significant. $\mathrm{Cd}-5$ and $\mathrm{Cd}-\mathrm{Hg} 5+20$ reduced the values of diversity index $\left(H^{\prime}\right)$ and evenness index $\left(J^{\prime}\right)(P<0.05)$; single $\mathrm{Cd}$ heighten the trophic diversity (TD), while the combination of $\mathrm{Cd}$ and $\mathrm{Hg}$ diminish TD $(P<0.05)$; $\mathrm{Hg}$ increased $\mathrm{f} / \mathrm{b}$ value, in contrast $\mathrm{Cd}-\mathrm{Hg}$ reduced the $\mathrm{f} / \mathrm{b}(P<0.05)$; heavy metal treatments moderately affected values of $\mathrm{MI}, \mathrm{SI}$ and $\mathrm{El}$ which fell in relative narrow limits throughout the experiment $(P>0.05)$ (Table 3 ).

\section{Nematode assemblage}

Bacteriovores were found to be the most abundant group in all treatments, they concentrated at $\mathrm{Cd}-\mathrm{Hg} 5+20$. Plant parasites were the second most common trophic group with highest proportion at $\mathrm{Cd}-5$. Fungivores were the third most frequent group, their highest relative abundance was found at $\mathrm{Hg}-20$ and the lowest was discovered at $\mathrm{Cd}-\mathrm{Hg} 5+20$ (Table 4).

Nematodes classed as c-p 1 and c-p 2 accounted for $87.67 \%$ of all nematodes identified (Table 4). Although the abundance of nematode dropped strongly in polluted soil, the proportion with c-p value 1 and 2 at $\mathrm{Hg}-20$ was much higher than that in the control. Both the highest proportion of $c-p 3$ group and the lowest proportion of $c-p$ 1 group occurred at $\mathrm{Cd}-5$. The relative importance of nematodes with a c-p value of 4 and 5 varied slightly among all treatments.

\section{Discussion}

Building on previous researches, population structure that was measured by abundance and genus number (Bakonyi et al., 2003), function indexes (MI, SI and EI) (Bongers, 1990; Korthals et al., 1996; Wang \& McSorley, 2005) and functional variables such as feeding groups (Yeates et al., 1993) and c-p groups (Bongers, 1990, 1999) were always applied to analyze the responses of nematode communities to disturbance.

The population of nematodes may increase or decrease with heavy metal concentration (Sánchez-Moreno \& Navas, 2007). In the present case the pronounced drop of nematode abundance already sent an alert on the heavy metal pollution (Table 4). Our result is different from previous findings by Bakonyi et al. (2003) who reported that $\mathrm{Cd}$ had a moderate influence on nematodes. This difference might be contributed by the short-term and high level of pollution. Cadmium could negatively impact on soil enzymatic activities and microbial community structure (Wang et al., 2019). We expect that the abundance of nematode was inhibited by the degradation of their feeding sources in contamination soil. In addition, $\mathrm{Hg}$ exposure can lead to multitoxicity, and most of these 


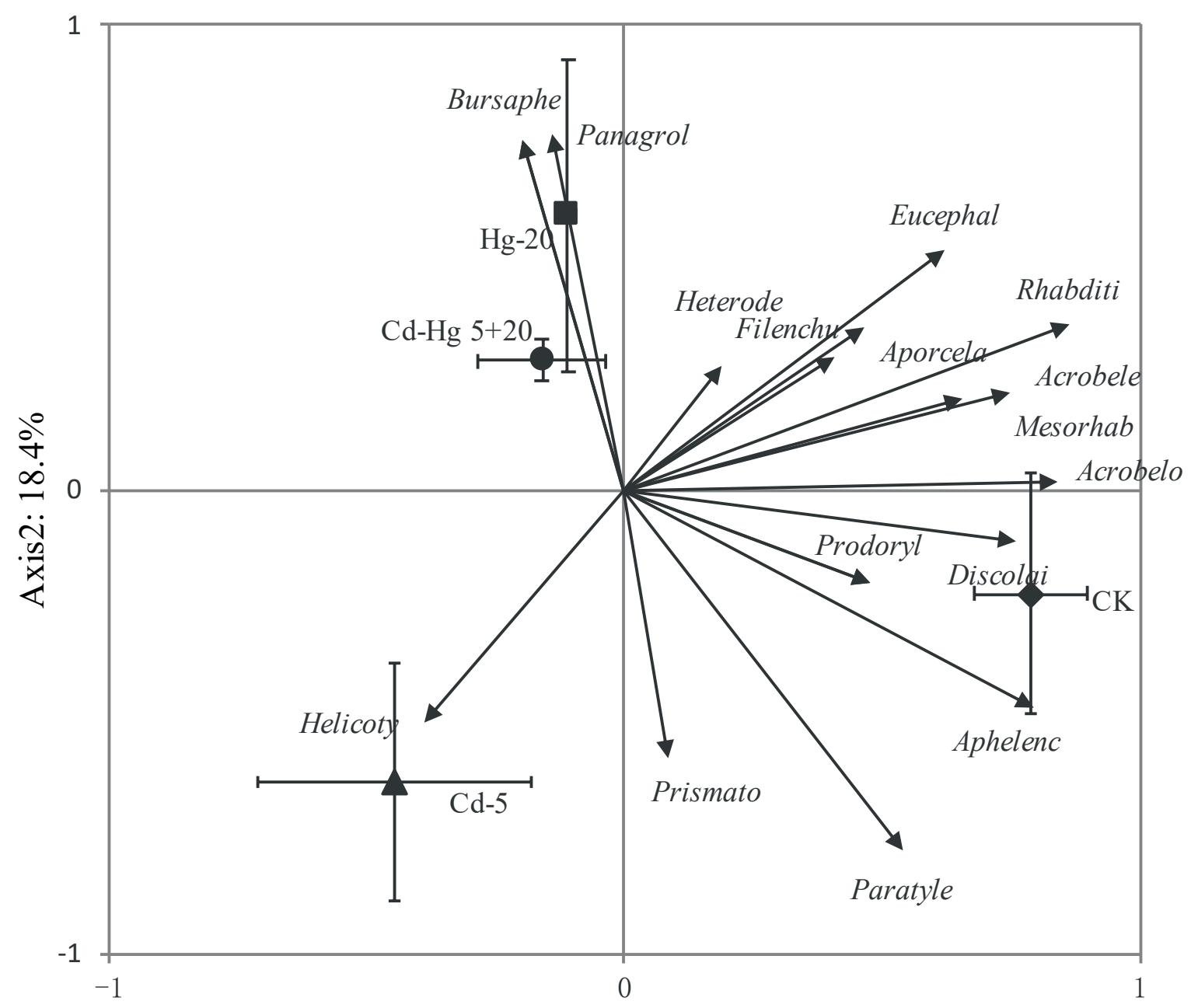

Axis $1: 32.2 \%$

Fig. 1. Principal components analysis (PCA) of nematode abundance in different treatments. Species fit range more than $20 \%$ were presented.

harmful effects on nematode can be transferred to progeny (Wu et al., 2010). Nematode diversity ( $\mathrm{H}^{\prime}$ ) and evenness (J') were lower at $\mathrm{Cd}-5$ and $\mathrm{Cd}-\mathrm{Hg} 5+20$ than the control and $\mathrm{Hg}-20$ (Table 3), which suggested single $\mathrm{Cd}$ and mixing of $\mathrm{Cd}$ and $\mathrm{Hg}$ create worse effects on nematode communities than single $\mathrm{Hg}$. Martinez et al. (2019) proposed that nematode-based environmental evaluations should be interpreted in a context-dependent way. Acidic soils can inhibit the diffusion of cadmium (Lu et al., 2005) and enhance its bioavailability (Kim et al., 2009), but the bioavailability of $\mathrm{Hg}$ tends to be lower in acidic soils (Mahbub et al., 2016). So the lower values of $\mathrm{pH}$ at $\mathrm{Cd}-5$ and $\mathrm{Cd}-\mathrm{Hg} 5+20$ seem to be the reason for the lower values of $\mathrm{H}^{\prime}$ and J'. Xie et al. (2011) found that the mixing of $\mathrm{Cd}$ and $\mathrm{Hg}$ had stronger toxic effects on soil microbial community than the single $\mathrm{Cd}$ or $\mathrm{Hg}$. Similarly, nematode trophic diversity index (TD) was lowest at $\mathrm{Cd}-\mathrm{Hg} 5+20$, which indicated the combination of $\mathrm{Cd}$ and $\mathrm{Hg}$ exert more adverse impacts on nematode trophic groups than individual $\mathrm{Cd}$ or $\mathrm{Hg}$ in this study.
Nematode assemblage and function level structure presented by $\mathrm{MI}, \mathrm{SI}$ and El was found to be skewed away from the theory of these indices which predicts a reduction of the $\mathrm{MI}$ and $\mathrm{SI}$ as a consequence of heavy metal pollution. The values of $\mathrm{MI}, \mathrm{SI}$ and $\mathrm{EI}$ were relatively uniform throughout all treatments. Our result was in line with Martinez et al. (2018) who discovered a short range for maturity index from different levels of disturbance. The reason for this phenomenon is the rarity and stabilization of relative abundance of high $c-p$ value groups among all treatments. Therefore, we propose that changes in nematode communities could be represented better from abundance and diversity point of view. Since MI, SI and El are expanded indices derive from proportions of feeding groups and life-history strategies, current findings highlight that more detailed analysis about trophic and c-p groups are needed for a correct interpretation of short-term high level pollution effects on soil nematodes. 
Table 4. Absolute abundance (individuals per $100 \mathrm{~g}$ dry soil) and relative abundance (\%) of nematode guilds in control and polluted pots.

\begin{tabular}{|c|c|c|c|c|}
\hline \multicolumn{5}{|c|}{ Absolute abundance } \\
\hline & $\mathrm{CK}$ & $\mathrm{Cd}-5$ & $\mathrm{Hg}-20$ & $\mathrm{Cd}-\mathrm{Hg} 5+20$ \\
\hline BF1 & $120.51 \pm 11.68 a$ & $8.40 \pm 4.84 \mathrm{c}$ & $30.88 \pm 1.56 b$ & $23.6 \pm 4.43 b$ \\
\hline BF2 & $327.48 \pm 26.67 a$ & $50.04 \pm 4.38 b$ & $57.36 \pm 6.00 b$ & $74.68 \pm 8.11 b$ \\
\hline BF3 & $14.16 \pm 8.31 a$ & $8.28 \pm 4.22 \mathrm{ab}$ & $0.00 \pm 0.00 \mathrm{~b}$ & $3.88 \pm 1.49 a b$ \\
\hline BF4 & $17.61 \pm 11.09 a$ & $0.00 \pm 0.00 \mathrm{~b}$ & $0.00 \pm 0.00 \mathrm{~b}$ & $9.61 \pm 2.39 a$ \\
\hline FF2 & $121.58 \pm 23.30 \mathrm{a}$ & $19.52 \pm 2.79 b$ & $52.92 \pm 7.46 b$ & $14.93 \pm 2.96 b$ \\
\hline FF3 & $0.00 \pm 0.00 \mathrm{a}$ & $5.52 \pm 1.67 a$ & $0.00 \pm 0.00 a$ & $1.84 \pm 0.46 a$ \\
\hline PP2 & $152.25 \pm 5.31 \mathrm{a}$ & $52.6 \pm 4.23 b$ & $8.80 \pm 2.55 \mathrm{c}$ & $13.92 \pm 2.25 c$ \\
\hline PP3 & $4.50 \pm 4.50 \mathrm{a}$ & $4.08 \pm 0.10 a$ & $2.20 \pm 2.20 \mathrm{a}$ & $3.72 \pm 3.72 a$ \\
\hline OP4 & $9.45 \pm 4.73 a$ & $2.42 \pm 1.21 \mathrm{~b}$ & $2.16 \pm 2.16 \mathrm{~b}$ & $3.68 \pm 1.49 b$ \\
\hline OP5 & $32.01 \pm 8.81 a$ & $0.00 \pm 0.00 \mathrm{~b}$ & $4.45 \pm 2.25 b$ & $3.87 \pm 1.94 b$ \\
\hline $\mathrm{BF}$ & $492.05 \pm 48.55 a$ & $67.61 \pm 16.46 c$ & $88.21 \pm 14.12 b c$ & $115.67 \pm 43.74 b$ \\
\hline $\mathrm{FF}$ & $121.58 \pm 23.30 \mathrm{a}$ & $25.14 \pm 7.15 c$ & $52.92 \pm 7.46 b$ & $16.74 \pm 6.72 \mathrm{c}$ \\
\hline PP & $156.91 \pm 9.83 a$ & $56.28 \pm 4.89 b$ & $11.45 \pm 3.97 \mathrm{c}$ & $17.98 \pm 6.55 c$ \\
\hline OP(c-p 4-5) & $42.26 \pm 13.04 a$ & $2.42 \pm 1.21 b$ & $6.61 \pm 2.66 b$ & $7.84 \pm 3.72 b$ \\
\hline$c-p 1-2$ & $727.47 \pm 49.04 a$ & $130.48 \pm 14.24 b$ & $150.12 \pm 21.96 b$ & $125.92 \pm 24.92 b$ \\
\hline$c-p$ 3-5 & $85.71 \pm 30.07 a$ & $20.32 \pm 6.31 b$ & $8.84 \pm 6.68 b$ & $27.06 \pm 7.40 \mathrm{~b}$ \\
\hline \multicolumn{5}{|c|}{ Relative abundance (\%) } \\
\hline & CK & Cd-5 & $\mathrm{Hg}-20$ & $\mathrm{Cd}-\mathrm{Hg} 5+20$ \\
\hline $\mathrm{BF}$ & $60.69 \pm 4.31 b$ & $42.00 \pm 3.06 c$ & $55.52 \pm 0.50 b$ & $73.43 \pm 5.71 a$ \\
\hline $\mathrm{FF}$ & $15.30 \pm 3.23 b$ & $12.21 \pm 2.43 b$ & $30.54 \pm 1.27 a$ & $7.66 \pm 1.63 c$ \\
\hline PP & $18.17 \pm 1.69 b$ & $38.85 \pm 7.75 a$ & $9.70 \pm 1.57 \mathrm{~b}$ & $12.59 \pm 4.84 b$ \\
\hline $\mathrm{OP}(c-p$ 4-5) & $5.84 \pm 1.99 a$ & $6.94 \pm 2.65 a$ & $4.23 \pm 0.68 a$ & $6.32 \pm 2.57 a$ \\
\hline$c-p 1-2$ & $89.53 \pm 2.31 a b$ & $86.33 \pm 3.96 b$ & $94.58 \pm 2.09 a$ & $82.10 \pm 5.07 b$ \\
\hline$c-p$ 3-5 & $11.62 \pm 3.33 \mathrm{ab}$ & $14.67 \pm 3.96 a$ & $5.42 \pm 2.09 b$ & $17.90 \pm 5.07 a$ \\
\hline
\end{tabular}

Mean values in a line with different letters are significantly different from each other at $P<0.05$; values are expressed as mean \pm standard error $(n=3)$. BF: bacterivores, FF: fungivores, PP: plant parasites, OP: omnivores-predators, numbers following the letters in Guild indicate the c-p value of each taxon

\section{Nematode trophic structure}

Distribution of soil nematodes within four trophic groups reflects their food-web relations and helps to investigate the trophic structure inside nematode community. Different trophic groups of nematode demonstrated their varied ability to adapt to the environment in present study. Bacteriovores are considered as species insensitive or resistant to various disturbances of environment (Nagy et al., 2004). Cd-Hg 5+20 which could produce greater side effects presented highest proportion of bacteriovores (Table 4). Among all the bacteriovores, Acrobeloides, Rhabditis were the dominant genera, which are partially comparable with results by Zhang et al. (2011). Martinez et al. (2012) demonstrated that the series of $\mathrm{Cd}$ concentrations did not significantly affect Acrobeloides. In contrast, the abundance of Acrobeloides in contaminated soil was extremely lower than in unpolluted soil. The steep decrease of Acrobeloides may result from the fact that heavy metal which likely concentrated around rhizosphere lead to the irregular ultrastructural changes in esophageal and intestinal cells of nematode, which cause the conflict of nutrient absorption and digestion (Harada, 2006). Consequently, Cd can decrease body growth (Álvarez et al., 2006) and reproductive capacity (Harada, 2006), which contributed to the lowest values for both absolute and relative abundance of bacteriovores.

Plant parasites may be affected more by vegetation than contents of heavy metals (Šalamún et al., 2011). Plant parasites were the second abundant trophic group (Table 4), and their proportion peaked at Cd-5. Jin and Wang (2019) found Cd (<30 mg/kg) promoted the growth of plants, moreover $\mathrm{Cd}$ could combine with car- 
boxyl functional groups, cellulose, proteins, lignin or hemicellulose on the cell wall to form precipitation, which helps plant parasites easily pierce the skin of roots and enhances their growth and reproduction. Helicotylenchus feeds mainly on the outside of the plant root (Sasser, 1989) only appeared at $\mathrm{Cd}-5$ and $\mathrm{Cd}+\mathrm{Hg} 5+20$, our result was partially in accordance with findings by Šalamún et al. (2011) who reported Helicotylenchus was dominate genus in heavy metal polluted soil. Plant feeding nematodes Paratylenchus was negatively correlated with the heavy metals (Zhang et al., 2007). Our data showed that Paratylenchus was the second abundant genus among all genera, its sub-adult stage made it have more advantage in adaptability. Ekschmitt et al. (2006) suggested Paratylenchus was a good candidate for substance-specific bioindication of $\mathrm{Cr}$.

High ratio of fungivores compared with bacterivores may be a mark of heavy metal contamination (Bongers \& Bongers, 1998). The highest proportion of fungivores at $\mathrm{Hg}-20$ resulted in the highest value of $f / b$. Our finding was partially in line with Pen-Mouratov et al. (2008) who reported that fungivores and plant parasites were the most two abundant groups near the source of heavy metal pollution. Since the functional diversity and genetic structure of microbial communities could be influenced by dramatic increase of $\mathrm{Hg}$ (20 mg/kg) (Harris-Hellal et al., 2008), and fungi are more tolerant than bacteria to heavy metal pollution (Rieder et al., 2013), the relationship between fungivores and their food source fungi in polluted soil should be further investigated .

\section{C-p group structure}

Investigation of the c-p group structure of the nematode assemblage is a useful method to detect heavy metal pollution (de Goede et al., 1993; Bongers \& Ferris, 1999). It is worthy to notice that bacteriovores with c-p1 nematodes were fewest at $\mathrm{Cd}-5$, lower $\mathrm{pH}$ might result in the lack of $c-p 1$ nematodes. Similar result can be found in the study of Sánchez-moreno and Navas (2007) who obtained that BF1 and BF2 nematodes were more abundant in the control than the polluted area. Omnivores-predators are always classified as high c-p value groups, as k-strategists they are sensitive to environmental changes, so omnivores-predator was the least abundance trophic group in this investigation. However, the proportion of c-p4-5 didn't show any regular change, this can be explained by the significant decline of the total abundance of nematodes in polluted soil. Šalamún et al. (2011) also discussed that the proportion of omnivores-predator was surprisingly relatively constant, fluctuating around $15 \%$ at all sites. It is well known that $c-p 3$ group is more sensitive than c-p 1 and 2 group. Interestingly, nematodes classified as c-p 3 from different feeding groups all showed a tolerant response to disturbance rather than c-p 1-2 group at $\mathrm{Cd}-5$. This finding is partially in accordance with Korthals et al. (1996) who reported that some c-p groups with lower values were as sensitive as groups with higher values. Another interesting phenomenon was that even the two genera have the same feeding type and $c-p$ value, could have distinct responses to heavy metal pollution such as Acrobeles and Acrobeloides. Martinez et al. (2012) suggested that different bacterivorous species have different pollutant tolerances which influence their ecological interactions, then lead to a higher population fitness of one species under intensive pollution. The above analyses indicated that more deep investigations should be conducted to evaluate the relationship between the c-p groups and the sensitivities to disturbance especially in a short-term experiment.

\section{Conclusions}

After 3 months application, morning glories absorbed small part of heavy metals. Heavy metals had a deleterious effect on soil nematode assemblage, decreased nematode abundance, changed the structure of feeding groups and c-p groups. Single $\mathrm{Hg}$ seemed to have smaller impacts than $\mathrm{Cd}$, and single $\mathrm{Cd}$ and $\mathrm{Hg}$ had fewer side effects than $\mathrm{Cd}-\mathrm{Hg}$ on nematode communities. Direct analysis of nematode abundance, diversity, trophic and c-p groups could be more useful tools than some indices to assess the degree of soil disturbance in the short-term high level pollution experiment.

\section{Conflict of interest statement}

The authors declared that they have no conflicts of interest to this work. We declare that we do not have any commercial or associative interest that represents a conflict of interest in connection with the work submitted.

\section{References}

Alı, A.N., BernAL, M.P., Ater, M. (2004): Tolerance and bioaccumulation of cadmium by Phragmites australis grown in the presence of elevated concentrations of cadmium, copper, and zinc. Aquatic Botany., 80(3): 163 - 176. DOI: 10.1016/j.aquabot. 2004.08.008 Álvarez, O.A., Jager, T., Redondo, M.E., Kammenga, J.E. (2006): Physiological modes of action of toxic chemicals in the nematode Acrobeloides nanus. Environ Toxicol Chem., 25: 3230 - 3237. DOI: 10.1897/06-097R.1

BAKonYI, G., NAGY, P., KÁDÁr, I. (2003) Long-term effects of heavy metals and microelements on nematode assemblage. Toxicol Lett., (140 - 141): 391 - 401. DOI: 10.1016/S0378-4274(03)00035-3

Barker, K.R., Carter, C.C., Sasser, J.N. (1985): An Advanced Treatise on Meloidogyne, Methodology, Vol. 2. Raleigh, NC, North, Carolina State University Graphics, 223 pp.

Bongers, T. (1988): De Nematoden van Netherland. KNNV Bibliotheekuitgave 46, Netherlands, Pirola, Schrool, 408 pp.

BONGERS, T. (1990): The maturity index: an ecological measure of environmental disturbance based on nematode species composition. Oecologia, 83: 14 - 19. DOI: 10.1007/BF00324627

Bongers, T., Bongers, M. (1998): Functional diversity of nematodes. Appl Soil Ecol., 10: 239 - 251. DOI: 10.1016/S09291393(98)00123-1 
Bongers, A.M.T., FerRIS, H. (1999): Nematode community structure as a bioindicator in environmental monitoring. Trends Ecol Evol., 14: 224 - 228. DOI: 10.1016/S0169-5347(98)01583-3

Chen, B.D., TANG, X.Y., Zhu, Y.G., Peter, C. (2005): Metal concentrations and mycorrhizal status of plants colonizing copper mine tailings: potential for revegetation. Sci China Ser C: Life Sci (Suppl)., 1: 156 - 164. DOI: 10.1007/BF02889814

Cherian, S., Oliveira, M.M. (2005): Transgenic plants in phytoremediation: recent advances and new possibilities. Environ Sci Technol., 39: 9377 - 9390. DOI: 10.1021/es0511341

China National Environmental Monitoring Centre. (1997): Soil quality- determination of lead, cadmium-Graphite furnace atomic absorption spectrophotometry. GB/T 17141 - 1997. (In Chinese)

De Goede, R.G.M., Bongers, T., EtTema, C.H. (1993): Graphical presentation and interpretation of nematode community structure: C-P triangles. Med Fac Landbouww Univ Gent., 58: 743 - 750.

EKSCHMITT, K., KoRTHALS, G.W. (2006): Nematodes as sentinels of heavy metals and organic toxicants in the soil. $J$ Nematol., 38(1):13-19.

Fu, S.L., Coleman, D.C., Hendrix, P.F., Crossley, D.A. (2000): Responses of trophic groups of soil nematodes to residue application under conventional tillage and no-till regimes. Soil Biol and Biochem., 32 :1731 - 1741. DOI: 10.1016/S0038-0717 (00)00091-2

Harada, H., Kurauchi, M., HayashI, R., EkI, T. (2006): Shortened lifespan of nematode Caenorhabditis elegans after prolonged exposure to heavy metals and detergents. Ecotox Environ Safe., 66: 378 - 383. DOI: 10.1016/j.ecoenv.2006.02.017

Harris-Hellal, J., Vallaeys, T., Garnier-Zarli, E., Bousserrhine, N. (2008): Effects of mercury on soil microbial communities in tropical soils of French Guyana. Appl Soil Ecol., 41(1): 59 - 68. DOI: 10.1016/j.apsoil.2008.08.009

Hou, J. (2012): Screening of heavy metal resistance flower and accumulation characteristics research of Pharbitis nil tocadmium, chromium and mercury. M.S. thesis, China, Liaoning, Liaoning Normal University

JIN, H.J., WANG, H.X. (2019): Plant absorption and tolerance mechanism to heavy metal cadmium: research progress. Chinese Agric Sci Bull., 35(24): 52 - 57. (In Chinses)

KIM, J., Koo, S.Y., KIm, J.Y., LeE, E.H., LeE, S.D., Ko, K.S., Ko, D.C., CHO, K.S. (2009): Influence of acid mine drainage on microbial communities in stream and groundwater samples at Guryong Mine, South Korea. Environ Geol., 58: 1567 - 1574. DOI: $10.1007 /$ s00254-008-1663-8

Korthals, G.W., van de Ende, A., van Megen, H., Lexmond, T.M., KammenGA, J.E., Bongers, T. (1996): Short-term effects of cadmium, copper, nickel and zinc on soil nematodes from different feeding and life-history strategy groups. App/ Soil Ecol., 4: 107 - 117. DOI: 10.1016/0929-1393(96)00113-8

LI, Q., LIANG, W.J., Zhang, X.K., Mahamood, M. (2017): Soil Nematodes of Grasslands in Northern China. Hangzhou, Zhejiang University Press and London, Academic Press, 242 pp.

LI, M.S., Tong L.J. (2008): Specificity and ecological risk of heavy metal pollution in Liaoning sewage irrigation district Chinese J Eco-Agricul., 16(6): 1517 - 1522. DOI: 10.3724/ SP.J.1011.2008.01517 (In Chinese)

Liang, W.J., LAVIAN, I., SteinBerger, Y. (2001): Effect of agricultural management on nematode communities in a Mediterranean agroecosystem. Nematol., 33: 208 - 215. PMID: 19265883

LiAng, W.J., LI, Q., Jiang, Y., Chen, W.B., Wen, D.Z. (2003): Effect of cultivation on spatial distribution of nematode trophic groups in black soil. Pedosphere, 13: $97-102$.

Liao, Z.J. (1993): Environmental Chemistry of Microelements and Their Biology Effects. Beijing, Chinese Environmental Science Press, pp. $299-302$

LU, A.X., ZHang, S.Z., Shan, X.Q. (2005): Time effect on the fractionation of heavy metals in soils. Geoderma, 125(3 - 4): 225 234. DOI: $10.1016 /$ j.geoderma.2004.08.002

Lu, R.K. (1999): Methods of Soil Agricultural Chemistry Analysis. Beijing, Chinese Agricultural Science and Technology Press, pp. 109. (In Chinese)

Mahbub, K.R., Krishnan, K., Megharaj, M., Naidu, R. (2016): Mercury inhibits soil enzyme activity in a lower concentration than the guideline value. Bull Environ Contam Toxicol., 96:76 - 82. DOI: 10.1007/s00128-015-1664-8

MARTINEZ, J.G., Dos Santos, G., Derycke, S., Moens, T. (2012): Effects of cadmium on the fitness of, and interactions between, two bacterivorous nematode species. Appl Soil Ecol., 56: 10 - 18. DOI: 10.1016/j.apsoil.2012.02.001

MARTINEZ, J.G., Quiobe, S.P., Moens, T. (2019): Effects of mercury $(\mathrm{Hg})$ on soil nematodes: a microcosm approach. Arch Environ Con Tox., 77: 421 - 431. DOI: 10.1007/s00244-019-00652-7

Martinez, J.G., Torres, M.A., dos Santos, G., Moens, T. (2018): Influence of heavy metals on nematode community structure in deteriorated soil by gold mining activities in Sibutad, southern Philippines. Ecol Indic., 91: 712 - 721. DOI: 10.1016/j. ecolind.2018.04.021

Ministry of Ecology and Environment of the People's Republic of CHINA. (2013): Soil and sediment-Determination of mercury, arsenic, selenium, bismuth, antimony -Microwave dissolution/Atomic Fluorescence Spectrometry. HJ 680 - 2013. (In Chinese)

Nagy, P., Bakónyı, G., Bongers, T., Kádár, I., Fábián, M., Kiss, I. (2004): Effects of microelements on soil nematode assemblages seven years after contaminating an agricultural field. Sci Total Environ., 320(2 - 3): 131 - 143. DOI: 10.1016/j.scitotenv. 2003.08.006 Pen-Mouratov, S., Shukurov, N., Steinberger, Y. (2008): Influence of industrial heavy metalpollution on soil free-living nematode population. Environ Pollut., 152 (1): 172 - 183. DOI: 10.1016/j. envpol.2007.05.007

Pen-Mouratov, S., Rakhimbaev, M., Barness, G., Steinberger, Y. (2004): Spatial and temporal dynamics of nematode populations under Zygophyllum dumosum in arid environments. Eur J Soil Biol., 40: 31 - 46. DOI: 10.1016/j.ejsobi.2004.01.002

PILon-Smits, E. (2005): Phytoremediation. Annu Rev Plant Biol., 56: 15 - 39. DOI: 10.1146/annurev.arplant.56.032604.144214 
Rieder, S.R., Brunner, I., Daniel, O., Liu, B., Frey, B. (2013): Methylation of mercury in earthworms and the effect of mercury on the associated bacterial communities. Plos One, 8(4):e61215. DOI: 10.1371/journal.pone. 0061215

Šalamún, P., Renčo, M., Miklisová, D., Hanzelová, V. (2011): Nematode community structure in the vicinity of a metallurgical factory. Environ Monit Assess., 183(1 - 4): 451 - 464. DOI 10.1007/ s10661-011-1932-y

SánCHEZ-MORENO, S., NavAS, A. (2007): Nematode diversity and food web condition in heavy metal polluted soils in a river basin in Southern Spain. Eur J Soil Biol., 43(3): 166 - 179. DOI: 10.1016/j. ejsobi.2007.01.002

SASSER, J.N. (1989): Plant-Parasitic Nematodes: The Farmer's Hidden Enemy. Raleigh, USA, North Carolina State University Press, $115 \mathrm{pp}$

Shannon, C. E., Weaver, W. (1949). The mathematical theory of communication. Urbana and Chicago, USA, University of Illinois Press, $144 \mathrm{pp}$.

SteinBerger, Y., SARIG, S. (1993): Response by soil nematode populations and the soil microbial biomass to a rain episode in the hot, dry Negev Desert. Biol Fertil Soils., 16: 188 - 192. DOI: 10.1007/ BF00361406

WANG, K.H., McSORLEY, R. (2005): Effect of soil ecosystem management on nematode pests, nutrient cycling, and plant health. Online APSnet Features, DOI:10.1094/APSnetFeatures/2005-0105.

Wang, L.J., Zhang, W.J., Wang, J.H., Zhu, L.S., Wang, J., Yan, S.H., AнMAD, Z. (2019): Toxicity of enrofloxacin and cadmium alone and in combination to enzymatic activities and microbial community structure in soil. Environ Geochem Hlth., 1 - 14. DOI: 10.1007/ s10653-019-00307-5

Wu, Q.L., Yang, P., Wang, D.Y. (2010): Mercury exposure can cause transferable defects of phenotypes and behaviors in nem- atode Caenorhabditis elegans progeny. J Southest Univ (Med Sci Edi)., 29(1): 1 - 9. DOI: 103969/j.issn.1671-6264.2010.01.001 XIA, Y.S., LI, F.B., WAN, H.F., MA, J., YAng, G.Y., Luo, W., Zhang, T.B. (2004): Spatial distribution of heavy metals of agricultural soils in Dongguan, China. J Environ Sci., 16: 912 - 918. DOI:10010742(2004)06-0912-07

XIE, X.M., LIAO, M., MA, A.L., ZHANG, H.J. (2011): Effects of contamination of single and combined cadmium and mercury on the soil microbial community structural diversity and functional diversity. Chin J Geochem., 30(3): 366 - 374. DOI: 10.1007/s11631-011-0521-7 Xu, J.B., Wang, J.N., Chl, J.G., QuU, W.D., GaO, Y.C., Zhang, Q. (2012): Study on the bioremediation of contaminated soil by petroleum and Cd. Safety Environ Eng., 19(3): 29 - 32. DOI:16711556(2012)03-0029-04 (In Chinese)

Yeates, G.W., Bongers, T., De Goede, R.G.M., Freckman, D.W., GEORGIEVA, S.S. (1993): Feeding habits in soil nematode families and genera-an outline for ecologists. J. Nematol., 25(3): 315-331. Yoon, J.M., Oliver, D.J., SHanks, J.V. (2007): Phytotoxicity and phytoremediation of 2, 6-dinitrotoluene using a model plant, Arabidopsis thaliana. Chemosphere, 68:1050 - 1057. DOI:10.1016/j. chemosphere.2007.02.003

Yu, Z.H., HuAng, G.P., Zhang, H, LI, Q.H., ZHONG, S.Q., Zhang, Y.T., SHANG, L.H. (2017): Distribution and pollution assessment of heavy metals in paddy soil in Danzhai Au-Hg mining area, Guizhou, China. Chinese J Ecol., 36(8): 2296 - 2301. DOI: 10.13292/j.10004890.201708.035 (In Chinese)

Zhang, W.D., Wang, X. F., LI, Q., JiAng, Y., LIANG, W.J. (2007): Soil nematode responses to heavy metal stress. Helminthologia, 44 (2): 87 - 91. DOI: 10.2478/ s11687-007-0009-5

Zhang, W.D., XIAO, Y., Shang, Y.F., LV, Y. (2011): Soil nematode community characteristics around the Gangue hill of Fushun West Open-pit mine. Helminthologia, 48 (2): 116 - 123. DOI: 10.2478/ s11687-011-0018-2 